\title{
Comparison of Ketamine, Fentanyl and Clonidine as an Adjuvant During Bupivacaine Caudal Anaesthesia in Paediatric Patients
}

\author{
Singh J, ${ }^{1}$ Shah RS, ${ }^{1}$ Vaidya $N,{ }^{1}$ Mahato $\mathrm{PK}^{,}{ }^{2}$ Shrestha $\mathrm{S},{ }^{2}$ Shrestha $\mathrm{BL}^{3}$
}

\author{
${ }^{1}$ Department of Anesthesia \\ ${ }^{2}$ Department of Surgery \\ ${ }^{3}$ Department of ENT \\ Kathmandu University School of Medical Science, \\ Dhulikhel Kavre, Nepal
}

\section{Corresponding author}

Jeevan Singh

Department of Anesthesia

Kathmandu University School of Medical Science Dhulikhel Kavre, Nepal

Email: drjeevan25@gmail.com

\section{Citation}

Singh J, Shah RS, Vaidya N, Mahato PK, Shrestha S, Shrestha BL. Comparison of Ketamine, Fentanyl and Clonidine as an Adjuvent During Bupivacaine Caudal Anesthesia in Pediatric Patients. Kathmandu Univ Med J 2012;39(3):25-29.

\begin{abstract}
Background

Caudal epidural analgesia with bupivacaine is very popular in paediatric anaesthesia for providing intra- and postoperative analgesia. Several adjuvants have been used to prolong the action of bupivacaine.
\end{abstract}

\section{Objectives}

To compare the efficacy of ketamine, fentanyl and clonidine in terms of quality and duration of analgesia they produce when added with caudal bupivacaine by single shot technique in children.

\section{Methods}

Eighty children, age one to ten years, undergoing sub-umbilical surgery, were prospectively randomized to one of four groups: caudal analgesia with $0.75 \mathrm{ml} /$ $\mathrm{kg}$ of $0.25 \%$ bupivacaine in normal saline (Group B) or caudal analgesia with 0.75 $\mathrm{ml} / \mathrm{kg}$ of $0.25 \%$ bupivacaine with $1 \mu \mathrm{g} / \mathrm{kg}$ of clonidine in normal saline (Group BC) or caudal analgesia with $0.75 \mathrm{ml} / \mathrm{kg}$ of $0.25 \%$ bupivacaine with ketamine $0.5 \mathrm{mg} / \mathrm{kg}$ (Group BK) or caudal analgesia with $0.75 \mathrm{ml} / \mathrm{kg}$ of $0.25 \%$ bupivacaine with fentanyl $1 \mathrm{mcg} / \mathrm{kg}$ (Group BF). Post-operative pain was assessed for 24 hours using the FLACC scale.

Results

The mean duration of analgesia was significantly longer in Group BC $(629.06 \pm 286.32$ $\mathrm{min}$ ) than other three groups $P<0.05$. The pain score assessed using FLACC scale was compared between the four groups, and children in Group BC had lower pain scores, which was statistically significant. The requirement of rescue medicine was lesser in Group BC. Clonidine in a dose of $1 \mu \mathrm{g} / \mathrm{kg}$ added to $0.25 \%$ bupivacaine for caudal analgesia, during sub-umbilical surgeries, prolongs the duration of analgesia of bupivacaine, without any side effects in compare to fentanyl or ketamine.

\section{Conclusion}

We conclude that clonidine in a dose of $1 \mu \mathrm{g} / \mathrm{kg}$, added to $0.25 \%$ bupivacaine for caudal analgesia and administered as a $0.75 \mathrm{ml} / \mathrm{kg}$ mixture in children, for subumbilical surgery, significantly prolongs the duration of post-operative analgesia when compared to $0.75 \mathrm{ml} / \mathrm{kg}$ of $0.25 \%$ bupivacaine in normal saline than 0.75 $\mathrm{ml} / \mathrm{kg}$ of $0.25 \%$ bupivacaine with ketamine $0.5 \mathrm{mg} / \mathrm{kg}$ or $0.75 \mathrm{ml} / \mathrm{kg}$ of $0.25 \%$ bupivacaine with fentanyl $1 \mathrm{mcg} / \mathrm{kg}$ or $0.75 \mathrm{ml} / \mathrm{kg}$ of $0.25 \%$ bupivacaine alone, without any side effects.

\section{KEY WORDS}

Bupivacaine, caudal analgesia, clonidine, fentanyl, ketamine, post-operative analgesia, sub-umbilical surgery 


\section{INTRODUCTION}

The International Association for Study of Pain (IASP) defines pain as an "unpleasant sensory and emotional experience associated with actual or potential tissue damage, or described in terms of such damage". ${ }^{1}$

Clinicians have adapted a number of analgesic strategies to minimize the pain during and after surgeries in pediatric patients and caudal epidural is one among them. It is the most popular and commonly performed technique in children. ${ }^{2}$ It is widely accepted due to technical simplicity. It is reliable, safe and can be used with general anesthesia for providing intra-operative and post-operative analgesia in patients coming for sub umbilical surgeries. ${ }^{2}$ Control of pain during intra-operative and post-operative period is important in pediatric patients as poor pain control may result in morbidity and mortality. ${ }^{3}$ Caudal epidural anesthesia / analgesia are the most widely employed technique for various surgical procedures within the distribution of T10 - S5 dermatome. ${ }^{4}$

The main disadvantage of caudal anesthesia is the short duration of action after a single injection of local anesthetic solution. Even long-acting local anesthetic drugs such as bupivacaine provide only four to eight hours of analgesia. The use of caudal catheters to administer repeated doses or infusions of local anesthetic solution is not popular, partly because of concerns about infection. So prolongation of caudal analgesia using a 'single-shot' technique has been achieved by the addition of various adjuvants. Adjuvant drugs are agents that when co-administered with local anesthetic agents improve the speed of onset, the quality and/or duration of analgesia. A wide range of drugs have

Table 1. The FLACC scale for pain assessment in children. There are five parameters, each given a score of $0-2$ and the total score is taken to assess pain.

\begin{tabular}{|c|c|c|c|}
\hline \multirow[t]{2}{*}{ Category } & \multicolumn{3}{|c|}{ Scoring } \\
\hline & 0 & 1 & 2 \\
\hline Face & $\begin{array}{l}\text { No particular } \\
\text { expression or } \\
\text { smile }\end{array}$ & $\begin{array}{l}\text { Occasional } \\
\text { grimace or frown, } \\
\text { withdraw, disin- } \\
\text { terested }\end{array}$ & $\begin{array}{l}\text { Frequent } \\
\text { to constant } \\
\text { quivering chin } \\
\text { clenched jaw }\end{array}$ \\
\hline Legs & $\begin{array}{l}\text { Normal position } \\
\text { or relaxed }\end{array}$ & $\begin{array}{l}\text { Uneasy, restless, } \\
\text { tense }\end{array}$ & $\begin{array}{l}\text { Kicking or } \\
\text { legs drawn up }\end{array}$ \\
\hline Activity & $\begin{array}{l}\text { Lying quietly, } \\
\text { normal position, } \\
\text { moves easily }\end{array}$ & $\begin{array}{l}\text { Squirming, shifting } \\
\text { back and forth, } \\
\text { tense }\end{array}$ & $\begin{array}{l}\text { Arched, rigid } \\
\text { or jerking }\end{array}$ \\
\hline Cry & $\begin{array}{l}\text { No cry (awake } \\
\text { or asleep ) }\end{array}$ & $\begin{array}{l}\text { Moans or whim- } \\
\text { pers; occasional } \\
\text { complaint }\end{array}$ & $\begin{array}{l}\text { Crying steadi- } \\
\text { ly, screams } \\
\text { or sobs, } \\
\text { frequent } \\
\text { complaints }\end{array}$ \\
\hline Consolability & Content, relaxed & $\begin{array}{l}\text { Reassured by } \\
\text { occasional touch- } \\
\text { ing, hugging or } \\
\text { being talked; } \\
\text { distractable }\end{array}$ & $\begin{array}{l}\text { Diffcuilt to } \\
\text { console }\end{array}$ \\
\hline
\end{tabular}

Each of the five categories is scored from 0-2, resulting in total range of 0-10, FLACC $=$ Face, Legs, Activity, Cry , Consolabitily been assessed for neuraxial anesthesia. For example, ketamine, clonidine, fentanyl, midazolam, tramadol etc.

For the measurement of pain we used the FLACC scale. The Face, Legs, Arms, Cry, Consolability scale or FLACC scale is a measurement used to assess pain in children between the ages of $1-10$.The scale has 5 criteria which are each assigned a score of 0,1 or $2 .{ }^{5}$ ( table 1 ) We chose the FLACC score among other such as Oucher pain scale, Children's hospital of Eastern Ontario pain scale (CHEOPS), Observational pain/ discomfort scale (OPS), as it is easy to use, is validated and gives us an objective evaluation. ${ }^{6}$

\section{METHODS}

This is a prospective randomized control trial conducted in the department of Anesthesia from May, 2012 to September, 2012, after approval from the Institutional Review Committee. Convenient sample of 80 patients was included. Written informed consent was taken from parents and the patients were allocated into four groups according to random allocation number table each group containing 20 patients. Patients with ASA grade 1 and 2 coming for below umbilical surgeries that are under the age group age one to ten years weighing approximately between five to twenty kilograms were included in the study groups. Infection at the site of injection, bleeding disorders, patients who are on anticoagulant therapy, congenital anomalies of the spinal cord, congenital disorders, patients allergic to anesthetic drugs, surgeries extending more than 90 minutes, surgeries requiring anesthesia above T10 level, active CNS disorders and convulsive disorders were excluded from the study.

All patients were pre-medicated with inj. atropine $0.02 \mathrm{mg}$ / kg orally half an hour prior to surgery. In the operation theatre all patients were induced with halothane and oxygen and delivered through Jackson Rees modification of Ayres T piece. Standard monitoring was done using the pulse oximeter, heart rate, non-invasive blood pressure, ECG, and oxygen saturation were monitored after taking the baseline reading and continuous monitoring was done at every five minute interval for the first 30 minutes and there by every 10 minutes till the end of surgery. After securing appropriate gauge IV cannula, midazolam $0.15 \mathrm{mg} / \mathrm{kg}$ and propofol $2 \mathrm{mg} / \mathrm{kg}$ body weight was given and patient's airway was secured with LMA of appropriate size. The patients were maintained on oxygen 3 liters/minute and isoflurane 1 to $2 \%$ and patients were kept in spontaneous ventilation. They were carefully placed in left lateral position with both the legs flexed at hip at 90 degrees and at knee joints. Under strict aseptic precautions sacral hiatus was identified by palpating sacral cornu. Twenty three gauge hypodermic needle was introduced at 90 degree until a pop is felt and then angled down to enter the sacral hiatus in the cephalic direction. After negative aspiration for blood and CSF, the study drugs were introduced into the caudal space according to allocation. Group B received 
$0.75 \mathrm{ml} / \mathrm{kg}$ of $0.25 \%$ bupivacaine in normal saline, Group $\mathrm{BC}$ received $0.75 \mathrm{ml} / \mathrm{kg}$ of $0.25 \%$ bupivacaine with $1 \mu \mathrm{g} /$ $\mathrm{kg}$ of clonidine in normal saline, Group BK received 0.75 $\mathrm{ml} / \mathrm{kg}$ of $0.25 \%$ bupivacaine with ketamine $0.5 \mathrm{mg} / \mathrm{kg}$ and Group BF received $0.75 \mathrm{ml} / \mathrm{kg}$ of $0.25 \%$ bupivacaine with fentanyl $1 \mathrm{mcg} / \mathrm{kg}$. The caudal anaesthesia was given by anaesthesia technicians, who were blinded about the drugs being used. The patients were repositioned supine and after reconfirmation of bilateral ventilation surgery started. No other analgesics were given. At the end of the surgery isoflurane was discontinued; LMA removed in deep level of Anesthesia and thereafter suctioning of the oral cavity done. Duration of surgery and parameters were recorded and entered in performa sheets. Patients were then shifted to observation ward after they are awake and breathing room air and then to their respective wards.

In the post-operative period vital parameters like pulse rate, respiratory rate, systolic blood pressure, diastolic blood pressure, mean arterial pressure and oxygen saturation were monitored for two hours at 30,60 and 120 minutes respectively. Sedation was assessed by using sedation score. Assessment of sedation was done by sedation score at every hour for the first eight hours. Pain score was evaluated using objective pain score scale by a trained nurse for 24 hours or till discharge whichever was the first. Intra-operative or post-operative decrease in systolic blood pressure and heart rate more than $30 \%$ of the baseline values were considered as severe hypotension and bradycardia respectively. It was treated with IV fluids followed by inj. atropine IV, if necessary. Respiratory depression was considered if oxygen saturation less than $93 \%$ on breathing room air and if so supplemental oxygen via face mask was used at 4 liters per minute. The duration of analgesia is defined as the time between the caudal anesthesia and the first complaint of pain. If the score is more than 4 or if the patient complains of pain they were given oral paracetamol $10 \mathrm{mg} / \mathrm{kg}$ as rescue analgesia in the form of syrup/drops. Patient sedation score was defined as 1: Asleep, not arousable by verbal contact 2: Asleep, arousable by verbal contact, 3: Drowsy, not sleeping, 4: Alert/ awake. ${ }^{7}$ The time of first micturation, post-operative nausea and vomiting, itching or any other symptoms were noted before discharge.

Changes in the hemodynamic variables, heart rate (HR), systolic blood pressure (SBP), diastolic blood pressure (DBP), and mean arterial pressure (MAP), between the four groups were analyzed with ANOVA (analysis of variance) using general linear model for repeated measures (SPSS- 17, Multi language) and by Student's t-test with Bonferroni's corrections. Changes in the hemodynamic variables within the groups were analyzed with multiple paired t-tests with Bonferroni's corrections. Demographic data and baseline hemodynamic values of were analyzed using either student's t-test or chi-square test. A $p$ value $\leq 0.05$ was considered statistically significant. Values are presented as mean \pm standard deviation.

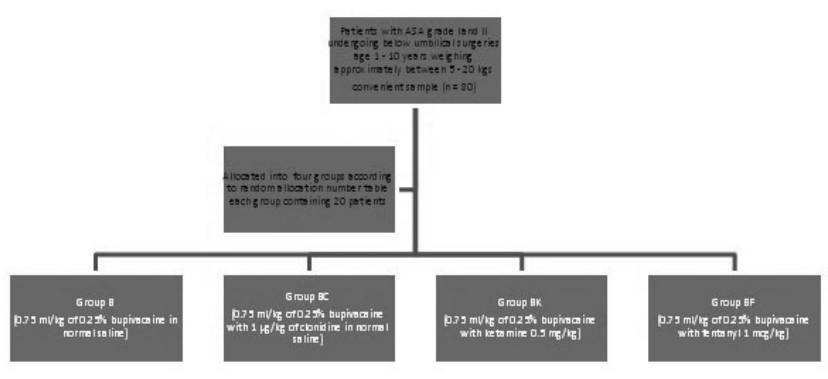

Figure 1. Randomization flowchart.

\section{RESULTS}

The results were analyzed in relation to age, weight of the patients, duration of anesthesia in minutes, recovery to first analgesia time (table 2), systolic, diastolic and mean arterial pressure, heart rate, respiratory rate and pain scale in 24 hours in postoperative period and post-operative complications like nausea, vomiting, hypotension, hypertension, pruritis, constipation, bradycardia and urinary retention.

All the four groups were comparable in relation to age and weight without any significant differences. Duration of anesthesia was also similar without any statistically significant differences. (Table 2, 3)

Table 2. Different variables of the patient.

\begin{tabular}{llllll} 
& $\begin{array}{l}\text { Group B } \\
(\mathbf{n = 2 0})\end{array}$ & $\begin{array}{l}\text { Group BK } \\
(\mathbf{n = 2 0})\end{array}$ & $\begin{array}{l}\text { Group BF } \\
(\mathbf{n = 2 0})\end{array}$ & $\begin{array}{l}\text { Group BC } \\
(\mathbf{n}=\mathbf{2 0})\end{array}$ & $\begin{array}{l}\text { P } \\
\text { value }\end{array}$ \\
$\begin{array}{llllll}\text { Age in } \\
\text { Years }\end{array}$ & $6.10 \pm 2.19$ & $5.30 \pm 1.8$ & $5.70 \pm 2.8$ & $5.45 \pm 2.5$ & 0.731 \\
$\begin{array}{l}\text { Weight } \\
\text { in kg }\end{array}$ & $15.60 \pm 3$. & $16.85 \pm 4$. & $14.75 \pm 4.0$ & $14.70 \pm 3.8$ & 0.259 \\
\hline
\end{tabular}

Table 3. Duration of anaesthesia and analgesia in all groups

\begin{tabular}{|c|c|c|c|c|c|}
\hline & $\begin{array}{l}\text { Group B } \\
(n=20)\end{array}$ & $\begin{array}{l}\text { Group BK } \\
(n=20)\end{array}$ & $\begin{array}{l}\text { Group BF } \\
(n=20)\end{array}$ & $\begin{array}{l}\text { Group BC } \\
(n=20)\end{array}$ & $\begin{array}{l}P \\
\text { value }\end{array}$ \\
\hline $\begin{array}{l}\text { Duration } \\
\text { of Anes- } \\
\text { thesia in } \\
\text { minutes }\end{array}$ & $\begin{array}{l}43.00 \pm 14 \\
.72\end{array}$ & $\begin{array}{l}57.75 \pm 22 . \\
15\end{array}$ & $\begin{array}{l}45.25 \pm 16 \\
26\end{array}$ & $\begin{array}{l}46.50 \pm 16 \\
14\end{array}$ & 0.125 \\
\hline $\begin{array}{l}\text { Recovery } \\
\text { to } 1 \text { st an- } \\
\text { algesic in } \\
\text { minutes }\end{array}$ & $\begin{array}{l}529.07 \pm \\
166.00\end{array}$ & $\begin{array}{l}615.00 \pm 2 \\
92.73\end{array}$ & $\begin{array}{l}507.75 \pm 2 \\
22.64\end{array}$ & $\begin{array}{l}629.06 \pm 2 \\
86.32\end{array}$ & 0.786 \\
\hline
\end{tabular}

Values are mean $\pm S D$. Significance value is regarded as $P$ value $<0.05$

The mean duration of analgesia was significantly longer in Group BC (629.06 $\pm 286.32 \mathrm{~min})$ than in Group BK (615.00 $\pm 292.73 \mathrm{~min})$, Group BF (507.75 $\pm 222.64 \mathrm{~min})$ and Group $B(529.07 \pm 166.00 \mathrm{~min}) ; P<0.05$. The duration of analgesia provided range from 4.3 hours to 15.4 hours for $0.75 \mathrm{ml} /$ $\mathrm{kg}$ of $0.25 \%$ bupivacaine in normal saline, 7.8 and 22.4 hours for $0.75 \mathrm{ml} / \mathrm{kg}$ of $0.25 \%$ bupivacaine with $1 \mathrm{mcg} /$ $\mathrm{kg}$ of clonidine in normal saline (Group BC), 6.4 hours to 21.25 for $0.75 \mathrm{ml} / \mathrm{kg}$ of $0.25 \%$ bupivacaine with ketamine 
$0.5 \mathrm{mg} / \mathrm{kg}$ (Group BK) and 8.4 hours to 20.25 for $0.75 \mathrm{ml} / \mathrm{kg}$ of $0.25 \%$ bupivacaine with fentanyl $1 \mathrm{mcg} / \mathrm{kg}$ (Group BF).

The pain score assessed using FLACC scale was compared between the four groups, and children in Group BC had lower pain scores, which was statistically significant $(p<0.05)$. The requirement of rescue medicine was lesser in Group BC. Clonidine in a dose of $1 \mathrm{mcg} / \mathrm{kg}$ added to $0.25 \%$ bupivacaine for caudal analgesia, during sub-umbilical surgeries, prolongs the duration of analgesia of bupivacaine, without any side effects.

Sixty percentages of the patients in the Group BC, thirty percentages Group BK and twenty percentages in each Group BF and Group B did not required any analgesia. There was no statistically significant differences in systolic blood pressure, diastolic blood pressure, mean blood pressure, heart rate and level of pain score observed in the 24 hours postoperative period among all the four groups as shown in fig.2, 3.
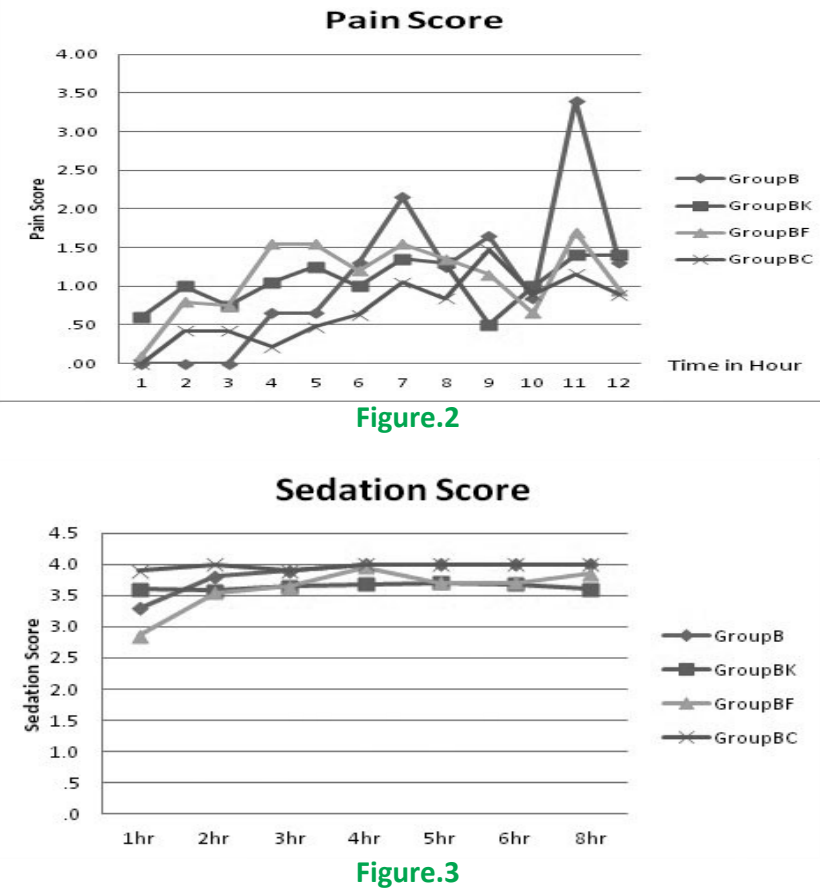

Post operatively nausea and vomiting occurred in $15 \%$, $10 \%$ and $5 \%$ of the patients in the bupivacaine group, bupivacaine-fentanyl group, bupivacaine- Ketamine group respectively and there was no incidence of such complications in the bupivacaine clonidine group. Urinary retention occurred in one of the patients in bupivacaine group and two in the bupivacaine fentanyl group respectively. There was one episode of itching in $B F$ group and $B$ group and one episode of hypertension in $B$ group and BK group. However other complication like respiratory depression, hypotension, bradycardia and constipation did not observed in any of the groups.

\section{DISCUSSION}

The key finding of this study is that the addition of $1 \mathrm{mcg} /$ $\mathrm{kg}$ of clonidine to caudal bupivacaine $0.25 \%$ significantly decreases the need for rescue analgesia in the immediate postoperative period. When $1 \mathrm{mcg} / \mathrm{kg}$ is added to $0.25 \%$ caudal bupivacaine, the quality of postoperative analgesia is equivalent to that produce with caudal ketamine $0.5 \mathrm{mg} /$ $\mathrm{kg}$ and caudal fentanyl $1 \mathrm{mcg} / \mathrm{kg}$. Although results differ widely, the duration of analgesia provided range from 6.3 hours to 16.4 hours for $1 \mu \mathrm{g} / \mathrm{kg}$ clonidine in adjuvant to $0.75 \mathrm{ml}$ per kg bupivacaine. ${ }^{6,7}$ One study has shown a mean duration of analgesia of $20.9 \pm 7.4$ hours in children receiving caudal clonidine with bupivacaine, but a dose of $5 \mu \mathrm{g} / \mathrm{kg}$ of clonidine was used in this study. ${ }^{8}$ The wide variation in the duration of action of clonidine in the various studies could be due to many reasons: dose of clonidine used, differences in pre-medication and volatile anesthetic used, type of surgery, indications for rescue analgesia, assessment of pain, and statistical analysis. The duration of analgesia in the clonidine group in our study was 10 hours, while that in the plain bupivacaine group was 4.5 hours, which was consistent with the study done by J.J. Lee et al where they compared in 46 children with bupivacaine $0.25 \% 1 \mathrm{ml} / \mathrm{kg}$ combined with normal saline and with bupivacaine $0.25 \%$ combined with clonidine $2 \mathrm{mcg} / \mathrm{kg}$ in normal saline for intra and postoperative analgesia and concluded that clonidine when added to bupivacaine improves the efficacy of caudal analgesia in children. ${ }^{9}$ Several adjuvants have been used to prolong the duration of analgesia of bupivacaine for caudal analgesia in children. Opioids, ketamine and midazolam are some of the commonly used drugs. ${ }^{10,11}$ The use of opioids is associated with an increased incidence of pruritus and post-operative nausea and vomiting. ${ }^{11}$ The advantage of clonidine is that it prolongs the duration of analgesia without an increase in the incidence of respiratory depression, pruritus and urinary retention which are commonly seen with neuraxial opioids.

Several mechanisms have been suggested for the clonidineinduced prolongation of caudal analgesia with bupivacaine. The anti-nociceptive action is due to the direct suppression of the spinal cord nociceptive neurons by epidural clonidine. Another mechanism is that clonidine crosses the blood brain barrier and interacts with alpha 2 adrenoceptors at spinal and supra-spinal sites to produce analgesia. Clonidine also suppresses neurotransmission in peripheral sensory $A \delta$ and $C$ nerve fibres. The final mechanism suggested is pharmacokinetically mediated: clonidine induces vasoconstriction through $\alpha-2 b$ adrenoceptors located at the peripheral vascular smooth muscles. ${ }^{12}$

We chose the FLACC scale to evaluate pain post-operatively as it is easy to use, is validated and gives us an objective evaluation. ${ }^{13}$

We chose to monitor our patients for a period of 24 hours post-operatively. This is in contrast to a few other studies where there was only a six-hour period of observation post-operatively and the rest of the assessment was done by parents. ${ }^{14,15}$ Assessment by parents could introduce some inconsistency as parents differ in the way they 
perceive their children to be in pain and the threshold for administering rescue medications varies between parents.

In contrast to our study, a study performed by Cook DJ et al comparing the effects of adrenaline, clonidine and ketamine on the duration of caudal analgesia in adjuvant with bupivacaine in children concluded that ketamine produced longer duration of analgesia compared to clonidine and adrenaline. ${ }^{10}$ Similarly a study performed by Martindale SJ et al demonstrate that ketamine prolongs the duration of post-operative analgesia. ${ }^{16}$

Naguib et al compared bupivacaine $0.25 \% 1 \mathrm{ml} / \mathrm{kg}$ with or without ketamine $0.5 \mathrm{ml} / \mathrm{kg}$ and ketamine $0.5 \mathrm{mg} / \mathrm{kg}$ with normal saline $1 \mathrm{ml} / \mathrm{kg}^{17}$ There was no significant difference in the quality of pain between the ketamine and the other two groups. The bupivacaine with ketamine group provided better analgesia with lesser side effects than with bupivacaine alone.

A meta-analysis of 18 trials by Curatalo et al in 2008 comparing epidural fentanyl, adrenaline and clonidine as adjuvants to local anaesthetics concluded that addition of fentanyl decreased the incidence of pain quantitatively during surgery and is a safe. ${ }^{18}$

\section{REFERENCES}

1. International Association for Study of Pain IASP. Classification of chronic pain. In:Mersky NB(ed). Task Force on Taxonomy; 1994. 2nd ed. p.209-14.

2. Daiens BJ. Regional Anaesthesia In Children. In: Miller RD, Eriksson LI, Fleisher LA, Wiener-Kronish JP, Young WL (eds). Miller's Anesthesia. 7th ed. Philadelphia: Churchill Livingstone; 2010. p.2519-57.

3. Hurley WR. Acute Postoperative Pain. In: Miller RD, Eriksson LI, Fleisher LA, Wiener-Kronish JP, Young WL (eds). Miller's Anesthesia. 7th ed. Philadelphia: Churchill Livingstone; 2010. p. 2757-81.

4. Sethna NF, Berde CB. Pediatric Regional Anesthesia. In: Gregory GA. Pediatric Anesthesia. 4th ed. Philadelphia: Churchill Livingstone; 2002. p.267-316

5. Malviya S, Voepel-Lewis T, Merkel S, Tait AR. The revised FLACC observational pain tool: improved reliability and validity for pain assessment in children with cognitive impairment. Paediatr Anaesth 2006;16(3):258-65.

6. Luz G, Innerhofer P, Oswald E, Salner E, Hager J, Sparr H. Comparison of clonidine $1 \mathrm{mcg} / \mathrm{kg}$ with morphine $30 \mathrm{mcg} / \mathrm{kg}$ for post-operative caudal analgesia in children. Eur J Anaesthesiol 1999;16:42-6.

7. Jamali S, Monin S, Begon C, Dubousset AM, Ecoffey C. Clonidine in pediatric caudal anesthesia. Anesth Analg 1994;78:663-6.

8. Yildiz TS, Korkmaz F, Solak M, Toker K. Clonidine addition prolongs the duration of caudal analgesia. Acta Anaesthesiol Scand 2006;50:501-4.

9. Lee JJ, Rubin AP. Comparison of a bupivacaine-clonidine mixture with plain bupivacaine for caudal analgesia in children. Br J Anaesth 1994;72:258-62.

10. Cook B, Grubb DJ, Aldridge LA, Doyle E. Comparison of the effects of adrenaline, clonidine and ketamine on the duration of caudal analgesia produced by bupivacaine in children. $\mathrm{Br} J$ Anaesth 1995;75:698-701.
Campbell FA et al compared the analgesic efficacy and safety of a single caudal injection of bupivacaine fentanyl mixture in a prospective, controlled, triple blinded study of 34 children, aged one to 11 years and ASA grade I\& II, undergoing urological surgery. ${ }^{19}$ They did not found any complications like nausea, vomiting, retention of urine and constipation, which is in contrasts to our study showing 10 $\%$ of retention in BF group and $5 \%$ in B group. Similarly $15 \%$ of the patients in BF group and $10 \%$ of the patients in $B$ group had nausea and vomiting which was in contrasts to their study. ${ }^{19}$

\section{CONCLUSION}

We conclude that clonidine in a dose of $1 \mu \mathrm{g} / \mathrm{kg}$, added to $0.25 \%$ bupivacaine for caudal analgesia and administered as a $0.75 \mathrm{ml} / \mathrm{kg}$ mixture in children, for sub-umbilical surgery, significantly prolongs the duration of postoperative analgesia when compared to $0.75 \mathrm{ml} / \mathrm{kg}$ of $0.25 \%$ bupivacaine in normal saline or with $0.75 \mathrm{ml} / \mathrm{kg}$ of $0.25 \%$ bupivacaine with ketamine $0.75 \mathrm{mg} / \mathrm{kg}$ or with $0.75 \mathrm{ml} / \mathrm{kg}$ of $0.25 \%$ bupivacaine with fentanyl $1 \mathrm{mcg} / \mathrm{kg}$ without any side effects.

11. Vetter TR, Carvallo D, Johnson JL, Mazurek MS, Presson RG. A comparison of single-dose caudal clonidine, morphine, or hydromorphone combined with ropivacaine in pediatric patients undergoing ureteral reimplantation. Anesth Analg 2007;104:1356-63.

12. Nishina K, Mikawa K. Clonidine in paediatric anaesthesia. Curr Opin Anaesthesiol 2002;15:309-16.

13. Merkel SI, Voepel-Lewis T, Shayevitz JR, Malviya S. The FLACC: A behavioral scale for scoring postoperative pain in young children. Pediatr Nurs 1997;23:293-7.

14. Koul A, Pant D, Sood J. Caudal clonidine in day-care paediatric surgery. Indian J Anaesth 2009;53:450-4.

15. Klimscha W, Chiari A, Michalek-Sauberer A, Wildling E, Lerche A, Lorber C. The efficacy and safety of a clonidine/bupivacaine combination in caudal blockade for pediatric hernia repair. Anesth Analg 1998;86:54-61.

16. Martindale SJ, Dix P, Stoddart PA. Double-blind randomized controlled trial of caudal versus intravenous $\mathrm{S}(+)$-ketamine for supplementation of caudal analgesia in children.Br J Anaesth2004;92:344-7.

17. Naguib M, Sharif AMY, Seraj M, Gammal EL,Dawlatly AA. Ketamine for Caudal Analgesia in Children: Comparision with Caudal Bupivacaine. Br J Anaesth1991;67: 559-64.

18. Curatalo M. Epidural fentanyl,adrenaline and clonidine as adjuvants to local anaesthetics for surgical analgesia:meta-analysis of analgesia and side-effects. Acta Anaesthesiol Scand2008;8:910-20.

19. Campbell FA, Yentis SM, Fear DW, Bissonnette B. Analgesic efficacy and safety of a caudal bupivacaine-fentanyl mixture in children. Can J Anaesth 1992: 39(7): 661-4. 